\title{
Historyczne i metodologiczne uwarunkowania współczesnego generatywizmu
}

Słowa klucze: Noam Chomsky, gramatyka generatywna, minimalizm, strukturalizm, definiowanie języka, biolingwistyka

\section{Wstęp}

Celem niniejszego artykułu jest przedstawienie wybranych zagadnień związanych z teorią gramatyki generatywnej Noama Chomsky'ego w szerszym kontekście historyczno-metodologicznym i filozoficznym ${ }^{1}$.

Nelson Goodman, jeden z najwybitniejszych dwudziestowiecznych filozofów amerykańskich, scharakteryzował swoje dokonania jako należące do tradycji filozofii nowożytnej, której źródłem było zastąpienie przez Kanta struktury świata strukturą umysłu, gdzie następnym krokiem było utożsamienie przez innego amerykańskiego filozofa i logika, C. I. Lewisa, struktury umysłu ze strukturą pojęć. Sam Goodman doszedł do ,utożsamienia struktury pojęć ze strukturą rozmaitych systemów symbolicznych nauki, filozofii, sztuki, percepcji oraz zwykłego dyskursu codzienności” (Goodman

${ }^{1}$ Niniejszy artykuł nawiązuje do głównych tez referatów, które przedstawiłem w trakcie LXVIII Zjazdu PTJ (Wrocław 2010) oraz w Komisji Teorii Języka PAN (Warszawa 2010). Uczestnikom tych zebrań wdzięczny jestem za komentarze i wszystkie uwagi krytyczne. Nieco inna wersja tego tekstu, Stalmaszczyk (2011), została złożona do druku w Biuletynie Polskiego Towarzystwa Językoznawczego. 
1997: 8). Można tu też wspomnieć o utożsamieniu struktury świata ze strukturą języka dokonanym przez wczesnego Ludwiga Wittgensteina, co dobrze widoczne jest np. w następujących tezach Traktatu: „Zdanie jest obrazem rzeczywistości” (4.01) i „Rzeczywistość porównuje się ze zdaniem” (4.05). Jak natomiast stosunkowo niedawno zauważył inny wybitny filozof amerykański, współtwórca teorii aktów mowy, John Searle, centrum zainteresowania $\mathrm{w}$ filozofii przesunęło się obecnie z języka na umysł, między innymi dlatego, że ,wiele problemów językowych to szczególne przypadki problemów umysłu" (Searle 2010: 20).

We wcześniejszych publikacjach (Stalmaszczyk 2006, 2011) postulowałem, żeby 'psychologiczny' i kognitywny aspekt teorii proponowanych przez gramatykę generatywną (np. Chomsky 1965, 1986, 2005; Rizzi 2004) i semantykę pojęciową (np. Jackendoff 2002, 2007) postrzegać jako kolejny krok w rozwoju współczesnej filozofii, jako 'kognitywną rewolucję w językoznawstwie' lub 'zwrot kognitywny' (nazwany tak przez analogię do 'zwrotu lingwistycznego' w filozofii), czyli przejście od badań struktury języka do badań struktury umysłu. Najnowsze prace Chomsky’ego (np. Chomsky 2005, 2007) można w tej perspektywie uważać za dotyczące zarówno językoznawstwa i filozofii języka, jak i, czy może nawet przede wszystkim, filozofii umysłu i biolingwistyki, rozumianej jako nauka badająca 'stany językowe umysłu' (Chomsky 2000: 2) i genetyczne uwarunkowania powstania języka rozumianego jako 'narząd poznawczy' (cognitive organ) charakterystyczny dla gatunku ludzkiego (Chomsky 2007: 2).

Jednocześnie należy podkreślić znaczenie samych teorii, ponieważ celem współczesnej nauki, co najmniej od czasu ustaleń Karla Poppera i Thomasa Kuhna, jest zrozumiałość teorii (a nie zrozumiałość świata), co może wiązać się z jeszcze innym postrzeganiem zdolności umysłu, zob. np. Chomsky (2002: 68). Należy również pamiętać, że wbrew zapewnieniom niektórych językoznawców, istnieją podstawowe różnice pomiędzy rozwojem teorii językoznawczych a rozwojem nauk przyrodniczych oraz formalnych, co wynika z zasadniczo innego sposobu prowadzenia badań, a także statusu ontologicznego samych bytów językowych (i językoznawczych)².

${ }^{2}$ Chomsky uważa (np. w: Chomsky 2002: 137), że dobrym wzorem dla językoznawstwa jest chemia, ale zob. zastrzeżenia wyrażone przez Lappina, Levina i Johnsona (2000). 
W niniejszym artykule zajmuję się dokonaniami Noama Chomsky'ego i jego autorską wersją gramatyki generatywnej rozwijanej w kilkunastu technicznych publikacjach książkowych, od The Logical Structure of Linguistic Theory (1955/1975) i Syntactic Structures (1957), po The Minimalist Program (1995), a także w setkach artykułów i wystąpień konferencyjnych na przestrzeni ostatnich 55 lat. Nie zajmuję się tu kwestią kolejnych 'rewolucji kognitywnych'3, przyjmuję natomiast tezę o 'kartezjańskim' i 'racjonalistycznym' modelu językoznawstwa generatywnego ${ }^{4}$ oraz o przynależności językoznawstwa generatywnego do szeroko pojętych nauk kognitywnych (czyli Cognitive Science w przeciwieństwie do Cognitive Linguistics zawężającego kognitywne pojmowanie językoznawstwa do osiągnięć R. Langackera, G. Lakoffa, M. Johnsona, L. Talmy'ego).

Gramatyka generatywna rozwijana przez Chomsky'ego stanowi próbę formalnego i w pełni wyartykułowanego opisu zasad i reguł gramatyki obecnej w umyśle idealnego mówcy-słuchacza, a dokładniej5: „Gramatyka stawia sobie za główny cel opis immanentnej kompetencji idealnego użytkownika języka. Jeżeli ponadto gramatyka jest całkowicie eksplicytna-innymi słowy, jeśli nie zdaje się na inteligencję domyślnego czytelnika, lecz raczej podaje pełną analizę jego języka osobniczego - to możemy (co poniekąd brzmi jak tautologia) nazywać ją gra matyką generaty w ną" (Chomsky [1982]: 17). Podejście to można określić też znacznie prościej: „Przez gramatykę generatywną rozumiem po prostu pewien system reguł, który w pewien ekspli-

3 O kolejnych 'rewolucjach kognitywnych' Chomsky pisze przede wszystkim w swoich pracach o bardziej filozoficznym charakterze, np. Chomsky $(2000,2002)$. W literaturze polskiej zob. dyskusję w: Pawelec (2008), Bobrowski (2009) i Wróbel (2010).

4 Teza ta została wyraźnie sformułowana już we wstępnych założeniach metodologicznych do Zagadnień teorii składni (Chomsky 1965 [1982]), zwłaszcza w rozdziale poświęconym organizacji gramatyki generatywnej (§3) i rozważaniach dotyczących teorii lingwistycznej w relacji do uczenia się języka (§8), a w pełni rozwinięta w książce Cartesian Linguistics (Chomsky 1966), zob. też obszerny wstęp do trzeciego wydania tej pracy, McGilvray (2009). Filozofii językoznawstwa generatywnego poświęcona jest praca Ludlow (2011).

5 Pierwszy w miarę pełny wykład gramatyki generatywnej ukazał się w pracy Chomsky’ego z 1957 roku, zob. Chomsky (1957), do wczesnej popularyzacji idei tam zawartych przyczyniła się obszerna (i entuzjastyczna) recenzja Roberta Leesa w Language, czasopiśmie LSA (Amerykańskiego Towarzystwa Językoznawczego), zob. Lees (1957). Bardzo ciekawą współczesną ocenę zawartych w Syntactic Structures pomysłów i rozwiązań przedstawia Lasnik (2000). 
cytny i ściśle określony sposób przyporządkowuje zdaniom opisy strukturalne" (Chomsky [1982]: 21).

\section{Kontekst historyczny}

Gramatyka generatywna nie powstała ex nihilo, przeciwnie, rozwijała się w określonym kontekście historycznym, zarówno lingwistycznym, jak i logiczno-filozoficznym. W tej części artykułu wspomnę pokrótce o niektórych historycznych uwarunkowaniach, a zwłaszcza o poglądach na język wynikających z logiki Gottloba Fregego, filozofii języka Ludwiga Wittgensteina, a także strukturalistycznych koncepcjach Ferdinanda de Saussure'a i Leonarda Bloomfielda.

Dla filozofii języka i formalnych badań nad językiem niezwykle istotne okazały się logiczne i semantyczne dokonania Fregego. Temat ten zdecydowanie wykracza poza skromne ramy niniejszego artykułu, tutaj zostaną przywołane jedynie postulaty Fregego dotyczące sformalizowania lub 'uporządkowania' języka naturalnego. W opublikowanej w 1879 r. pracy Begriffsschrift, eine der arithmetischen nachgebildete Formelsprache des reinen Denkens (Ideografia logiczna: sformalizowany język czystego myślenia wzorowany na arytmetyce ${ }^{6}$ Frege twierdzi, że zadaniem filozofii jest przełamywanie panowania słowa nad ludzką myślą ,przez odkrycie powstających w sposób nieunikniony złudzeń co do stosunków pomiędzy pojęciami, jak również przez to, że uwolni ona myśl od tego, czym obarcza ją sama tylko określoność językowych środków wyrazu” (Frege 1997a: 48). Narzędziem, które to umożliwi, jest zaprojektowany przez Fregego język formalny, czyli ideografia. W Przedmowie do Ideografii Frege porównuje język formalny do mikroskopu, z jego dostosowaniem do ostrości rozróżnień, w przeciwieństwie do języka potocznego, przyrównanego do ludzkiego oka, i zauważa w tym kontekście, że ,ideografia jest środkiem pomocniczym służącym określonym celom naukowym, którego nie należy ganić dlatego, że do innych się nie nadaje" (Frege 1997a: 47). Również w jednym z późniejszych listów do Edmunda Husserla, Frege podkreśla, że podstawowym zadaniem

6 Tak tłumaczy tytuł dzieła Fregego Bogusław Wolniewicz (Wolniewicz 1977: viii), natomiast w antologii pod redakcją i w przekładzie Krzysztofa Rottera tytuł brzmi: Ideografia. Język formalny czystego myślenia wzorowany na języku arytmetyki (Rotter 1997: 45). 
logików jest uwolnienie się od języka i jego uproszczenia, a logika powinna być 'sędzią języka' (Frege 1997b: 303). To podejście, a także późniejsze prace, m.in. Alfreda Tarskiego i Rudolfa Carnapa, umożliwiły powstanie badań formalnych nad składnią i semantyką języków naturalnych.

$\mathrm{Z}$ oczywistych względów zupełnie inne podejście do języka naturalnego propagował rozwijający się w pierwszej połowie XX w. strukturalizm, zarówno w wersji europejskiej (Ferdinanda de Saussure'a), jak i amerykańskiej (Leonarda Bloomfielda). Wśród licznych definicji zamieszczonych w Kursie językoznawstwa ogólnego warto w tym miejscu przytoczyć dwie już dziś klasyczne definicje języka, z których pierwsza zwraca uwagę na systemowy charakter języka, natomiast druga traktuje język jako byt indywidualny i zarazem społeczny: „Język jest systemem znaków wyrażających pojęcia” (1991: 43) oraz „Jest to równocześnie społeczny wytwór zdolności mowy oraz ogół niezbędnych konwencji przyjętych przez grupę społeczną, aby jednostki mogły z tej zdolności korzystać” (1991: 36). Na społeczny charakter języka zwracał uwagę również Bloomfield: „Ogół wypowiedzi, które mogą powstać we wspólnocie językowej to właśnie jest język tej wspólnoty" (1926: 155).

Sposób definiowania języka przez Chomsky'ego będzie tematem następnej części artykułu, teraz natomiast warto zwrócić uwagę na różnice pomiędzy patrzeniem na językoznawstwo przez de Saussure'a (i strukturalizm) oraz Chomsky'ego (i generatywizm). Poniższe diagramy pokazują miejsce językoznawstwa w obrębie nauk w obydwu paradygmatach:

Językoznawstwo strukturalne (de Saussure 1991: 42)

Psychologia ogólna

Psychologia społeczna
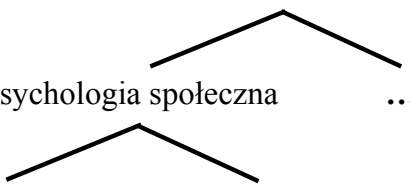

Semiologia

Językoznawstwo

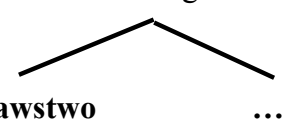


Językoznawstwo generatywne (Chomsky 2000: 1-2)

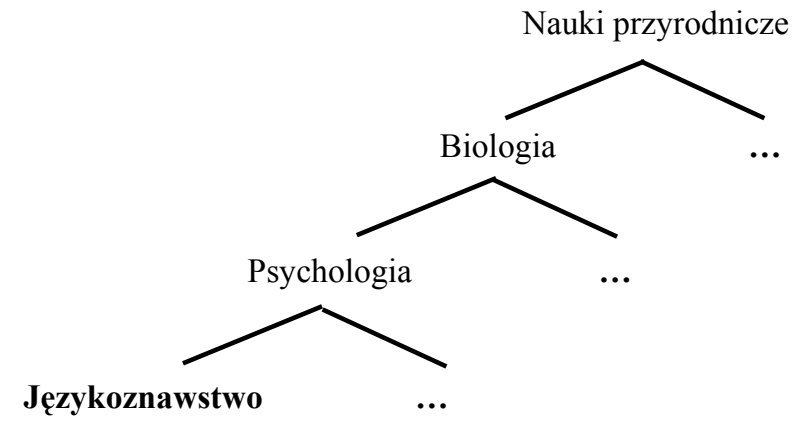

Na umiejscowienie przez Chomsky'ego językoznawstwa w obrębie (sformalizowanych) nauk przyrodniczych z pewnością duży wpływ mógł mieć Zellig Harris, który w latach 50. pracował nad matematycznymi podstawami analizy struktury językowej, również sam Chomsky wykorzystywał dokonania matematyków i logików (m.in. Rudolfa Carnapa i Emila Posta) ${ }^{7}$, m.in. rozwiązania przyjęte przez niego w Syntactic Structures w dużej mierze czerpią z teorii systemów kombinatorycznych Posta. Wprawdzie w Syntactic Structures Chomsky nie przywołuje Posta, ale już w Zagadnieniach teorii składni zauważa, że „termin 'generować' w zamierzonym tu sensie znany jest na gruncie logiki, szczególnie w teorii systemów kombinatorycznych Emila Posta" (Chomsky ([1982]: 22). Oczywiście, wpływ Posta jest znacznie istotniejszy niż samo przyjęcie terminu 'generowanie' i dotyczy samej koncepcji wprowadzenia tego mechanizmu formalnego do opisu gramatyki języków naturalnych, co przełożyło się na moc eksplanacyjną gramatyki generatywnej ${ }^{8}$.

Warto na marginesie tych rozważań zauważyć, że prawie w tym samym czasie w obrębie antropologii kulturowej (czy raczej jednej z ówczesnych szkół antropologicznych) Evans-Pritchard krytykował porównanie antropologii do nauk przyrodniczych i podkreślał, że odkrywane przez antropologię

7 Na temat źródeł (zarówno formalnych, jak i filozoficznych) gramatyki generatywnej, zob. Tomalin (2006). Barsky (1998) dokładnie omawia rolę różnych czynników naukowych, społecznych i politycznych mających wpływ na ukształtowanie się poglądów Chomsky'ego (zarówno lingwistycznych, jak i politycznych).

${ }^{8}$ O możliwym wpływie teorii algorytmów wypracowanej przez Posta na późniejszy program minimalistyczny wspomina Seuren (2004: 153). 
systemy moralne i symboliczne są niepodobne do systemów odkrywanych w przyrodzie, zob. Evans-Pritchard (1951: 62) .

\section{Pytania o język}

W pracy z 1957 roku, Syntactic Structures, Chomsky, po wstępnych rozważaniach na temat celu analizy składniowej i roli składni w opisie języka, definiuje język jako 'zbiór zdań” ${ }^{10}$ : „Od tej pory język będę uważać za zbiór (skończony lub nieskończony) zdań, każde o skończonej długości i skonstruowane ze skończonej ilości elementów" (Chomsky 1957: 13), a także, dla potrzeb analizy transformacyjnej: ,Język definiuje się poprzez podanie jego 'alfabetu' (to jest skończonego zbioru symboli, z których tworzy się zdania) oraz zdań gramatycznych" (Chomsky 1957: 21). Formalne zdefiniowanie języka, wprowadzenie mechanizmów (takich jak reguły struktury frazowej i reguły transformacyjne) umożliwiających opis właściwości różnorodnych struktur i wyjaśniających zachodzące pomiędzy nimi podobieństwa i różnice, a także zwrócenie uwagi na zjawisko rekursywności języka i jego formalny opis, miały wielkie znaczenie dla dalszego rozwoju językoznawstwa (nie tylko generatywnego), a także informatyki i wszelkich późniejszych technologii związanych z przetwarzaniem języka naturalnego. Z całą pewnością wczesna gramatyka generatywna (dla której reprezentatywne są prace Chomsky [1955], 1957, a także do pewnego stopnia 1965) należy do trwałych dokonań Chomsky’ego (a szerzej, współczesnego językoznawstwa), z perspektywy czasu być może te właśnie dokonania okażą się trwalsze niż wszelkie implikacje psychologiczne i mentalne późniejszej gramatyki generatywnej ${ }^{11}$.

9 Porównanie $\mathrm{z}$ antropologią jest tu nieprzypadkowe: antropologia, podobnie jak współczesne językoznawstwo, przeszła głęboką ewolucję - od kolekcjonowania i objaśniania 'faktów', do budowania i weryfikowania teorii.

10 Ta definicja pozornie przypomina sformułowanie Wittgensteina: „Język to ogół zdań" (TLP 4.001). Należy jednak pamiętać, że definicja Chomsky’ego ma charakter operacyjny, a Wittgensteina ontologiczny. Ważne jest tu również rozróżnienie (na które zwróciła mi uwagę prof. Barbara Lewandowska-Tomaszczyk) typ/okaz. W teorii Chomsky'ego istotna jest nie tyle kolekcja zdań, co procedura ich tworzenia i opisu, natomiast dla Wittgensteina pojedyncze zdania kumulują się do języka, a „Ogół zdań prawdziwych stanowi całość przyrodoznawstwa" (TLP 4.11).

11 Teza ta wymaga jednak odrębnego uzasadnienia, zwłaszcza że aspekt 'formalny’ dokonań Chomsky’ego łączy się ściśle z implikacjami dla wszelkiej teorii biologicznej: własnością ludzkiej zdolności językowej (opisanej w sposób formalny dzięki regu- 
Jak zauważył wybitny przedstawiciel brytyjskiego empiryzmu, Alfred Ayer, postęp (w filozofii) „nie polega na likwidacji odwiecznych problemów, ani na zwiększającej się dominacji tej czy innej ze spierających się sekt, ale na zmianie sposobu stawiania problemów i na rosnącej zgodności poglądów dotyczących natury ich rozwiązań” (Ayer 2000: 22), natomiast zgodnie z Kuhnowską wizją filozofii nauki ,istnienie paradygmatu wyznacza problem do rozwiązania" (Kuhn 2001: 60) ${ }^{12}$. W późniejszych ujęciach teorii generatywnej dochodzi do znaczącego przeformułowania pytań o język (i celów teorii lingwistycznej). W indywidualistycznej koncepcji języka, głównym przedmiotem badań staje się dla Chomsky’ego język przede wszystkim postrzegany jako organ mentalny, a problemem do rozwiązania jest udzielenie odpowiedzi na następujące pytania:

(1) 1. Co składa się na wiedzę o języku?

2. W jaki sposób wiedza ta zostaje nabyta?

3. Jak ją wykorzystujemy?

Powyższe pytania dotyczą gramatyki rozumianej jako struktura obecna w umyśle, jednakże aby dać na nie odpowiedź, potrzebna jest również gramatyka językoznawcy, czyli w tym przypadku eksplicytna gramatyka generatywna. W pracach z okresu tzw. teorii standardowej Chomsky charakteryzował Gramatykę Uniwersalną (Universal Grammar - UG) jako suplement do gramatyk poszczególnych języków, a także jako twórczy aspekt kompetencji językowej, zob. Chomsky (1965). UG stanowiła jednocześnie system warunków nakładających ograniczenia gramatykom wszystkich języków. W nowszych i najnowszych publikacjach Chomsky kładzie nacisk na fakt, że UG jest teorią charakteryzującą genetycznie zdeterminowany mechanizm akwizycji języka (Chomsky 1986, 2002, 2005). Mechanizm ten stanowi wrodzony składnik umysłu ludzkiego, dzięki któremu możliwe jest (poprzez interakcję

łom struktury frazowej oraz regułom transformacyjnym) jest możliwość wykorzystania skończonej liczby elementów do tworzenia nieskończonego zbioru większych jednostek językowych, jak zauważa w swoich pracach Chomsky (np. Chomsky 2002: 148), własność taka jest wyjątkowa w świecie biologicznym.

12 Na temat paradygmatów w językoznawstwie zob. Bobrowski (1998: 61-80), por. Willim (2010) na temat podejść formalnych i funkcjonalnych we współczesnym językoznawstwie, zob. również uwagi w Stalmaszczyk (2011). 
i konfrontację z przedstawionym materiałem językowym) nabywanie danego języka. Gramatyka jest systemem wiedzy, natomiast teoria gramatyki zajmuje się pewnym określonym stanem kognitywnym (a nie używaniem języka). Według Chomsky’ego Gramatyka Uniwersalna jest teorią stanu początkowego zdolności językowej (zapisaną w genach), natomiast gramatyki poszczególnych języków są teoriami stanów osiągniętych. Z pojęciem UG ściśle związane są pojęcia kompetencji (competence) i wykonania (performance), jednak w nowszych pracach Chomsky dokonuje rozróżnienia między językiem 'zinternalizowanym' a językiem 'zewnętrznym'. Język zinternalizowany, wewnętrzny (I-language - I-język), istnieje w umyśle idealnego mówcy/ słuchacza, jest to rzeczywistość umysłowa i wiedza (knowledge), stan zdolności opanowania języka (rodzimego). I-język to przeformułowane pojęcie kompetencji, kompetencja bowiem zbyt często była rozumiana (wbrew intencjom Chomsky'ego) w duchu langue de Saussure'a.

Podczas gdy I-język to rzeczywistość umysłowa (mentalna) i wiedza, to język zewnętrzny (E-language - E-język) jest zdefiniowany jako nieskończony zbiór zdań określanych i ograniczanych przez konwencje społeczne. E-język powiązany jest $\mathrm{z}$ wykonaniem i zachowaniem (i przypomina do pewnego stopnia parole w koncepcji de Saussure'a). Jest to także zbiór kolejnych przyporządkowań dźwięku, struktury i znaczenia. I-język nawiązuje do kompetencji gramatycznej, natomiast E-język do kompetencji pragmatycznej i komunikacyjnej (zob. Chomsky 1986, 1995a, 1995b, 1998, 2002). I-język jest stanem systemu obliczeniowego (computational system) umysłu/ mózgu, który generuje ustrukturyzowane wyrażanie językowe (zob. Chomsky 2005, 2007). W tych najnowszych pracach Chomsky'ego, z pogranicza językoznawstwa i filozofii umysłu, podstawowe pytanie związane jest z tzw. 'optymalnym projektem' (optimal design) i brzmi: czy język jest optymalnym narzędziem przetwarzania myśli ${ }^{13}$ ?

13 Zob. Chomsky (2002: 56-57): „Wydaje się teraz możliwe poważnie traktować ideę, która jeszcze niedawno uchodziłaby za dziwaczną, że językowy organ mózgu bliski jest optymalnemu projektowi”. Szerzej na temat biolingwistycznych założeń zob. Chomsky (2005, 2007; Rizzi 2004), z prac w języku polskim podejmuje te zagadnienia, w szerokim kontekście filozoficznym i psychologicznym, książka Szymona Wróbla: Wróbel (2010), obszerny przegląd współczesnej literatury oferuje także Ida Kurcz (2011), zob. również uwagi dotyczące założeń metodologicznych i filozoficznych podejścia Chomsky’ego w: Bobrowski (2009). Jednocześnie należy zauważyć, że według Chomsky’ego ów 'optymalny projekt' nie oznacza, iż ,język jest dobrze zaprojektowany po to, by go używać”, 
Według jeszcze innego sformułowania na język składają się trzy rodzaje elementów (Chomsky 2000: 10):

(2) 1. Właściwości dźwięków i znaczeń, zwane 'cechami';

2. Jednostki złożone z tych właściwości, zwane 'jednostkami leksykalnymi';

3. Złożone wyrażenia konstruowane $\mathrm{z}$ jednostek atomowych.

Próbą owego formalnego i precyzyjnego opisu UG była teoria Government-Binding ('rządu i wiązania' - GB) przedstawiona w licznych pracach Chomsky'ego z lat 80. (np. Chomsky 1981, 1982, 1986) ${ }^{14}$. Do najbardziej charakterystycznych cech tego modelu należały:

- uproszczony system reguł - wyeliminowanie reguł frazowych, ograniczenie liczby i siły oddziaływania transformacji;

- różne poziomy interpretacji (struktura głęboka, struktura powierzchniowa, forma logiczna, forma fonologiczna);

- modularność - współdziałanie różnych teorii składowych (modułów);

- wprowadzenie pustych (niezleksykalizowanych) kategorii;

- parametryzacja: każda ze składowych teorii GB dopuszcza możliwość więcej niż jednego rozwiązania, jednakże w ograniczonej ilości, dlatego może istnieć skończona ilość gramatyk ${ }^{15}$.

Najnowszą wersją gramatyki generatywnej jest tak zwany Program Minimalistyczny (Minimalist Program, zob. Chomsky 1995a, 1998, 2000, 2002, 2005), który zakłada jeszcze większe uproszczenie formalne w obrębie gramatyki generatywnej ${ }^{16}$. Język jest w programie minimalistycznym postrzega-

albowiem używanie języka do komunikacji to zjawisko wtórne (Chomsky 2002: 107), oraz w większości przypadków język używany jest dla/do siebie (Chomsky 2002: 148).

14 Szerzej na temat modelu GB i przejścia do minimalizmu zob. Willim (2010) i Stalmaszczyk (2006, 2011), tam też dokładna bibliografia tematu (z uwzględnieniem prac w języku polskim).

15 Parametrem może być np. rodzaj węzła ograniczającego albo szyk elementu dopełniającego (complement) względem podstawy (head) konstrukcji w teorii składni frazowej.

16 Z prac w języku polskim dotyczących minimalizmu należy wspomnieć o artykułach Przemysława Tajsnera (2006), Jacka Witkosia (2000, 2008), Ireneusza Bobrowskiego (2009) i Ewy Willim (2010), zob. też propozycje terminologiczne w: Mecner (2005). 
ny jako 'stan i procedura': „Konkretny język to stan zdolności opanowania języka (faculty of language). Język jest procedurą rekursywną, która generuje nieskończoną liczbę wyrażeń. Każde takie wyrażenie można uważać za zbiór informacji dla innych systemów umysłu i mózgu" (Chomsky 2002: 86-87). W tej definicji widać wyraźnie, charakterystyczne dla omawianego we wstępie zwrotu kognitywnego, przejście od analizy systemy językowego do analizy procedur mentalnych, przejście od wspomnianego w Syntactic Structures 'zbioru zdań' do 'zbioru informacji dla systemów umysłu i mózgu'.

Zamiast poziomów struktury D i S, Chomsky proponuje wprowadzenie jednego systemu generującego, który współpracuje granicznie (interface) z poziomami reprezentacji fonetycznej i semantyczno-logicznej. Jednym $\mathrm{z}$ podstawowych założeń badawczych minimalizmu jest skrócenie i uproszczenie derywacji składniowych. Składnia traktowana jest jako minimalny (czyli najprostszy teoretycznie i instrumentalnie) mechanizm wiążący w jedną całość warstwę dźwiękową i znaczeniową języka. W teorii rządu i wiązania wszystkie kategorie tworzą własne frazy, generowane zgodnie z regułami teorii składni frazowej wielostopniowej ( $X$-bar), minimalizm jednakże rezygnuje z tego mechanizmu (Chomsky 1995a: 246).

Zdania wygenerowane przez składnię muszą zostać zinterpretowane fonologicznie i semantycznie, a zatem język (rozumiany jako system generujący) 'graniczy' (interface) poprzez odpowiednie moduły z systemami wykonawczymi:

\section{(3) $\mathrm{A}-\mathrm{P} \longleftrightarrow \mathrm{FF} \leftarrow$ Język $\rightarrow$ FL $\longleftrightarrow$ K-I}

Język - system generujący;

FF, FL - forma fonologiczna i forma logiczna;

A-P, K-I - systemy wykonawcze: artykulacyjno-percepcyjny oraz konceptualno-intencjonalny

Minimalizm, podobnie jak wcześniejsze modele gramatyki generatywnej, zwłaszcza teoria rządu i wiązania, zakłada współistnienie w derywacji składniowej dwóch typów kategorii: leksykalnych i funkcjonalnych. Te kategorie składają się, między innymi, z cech formalnych. Dla kategorii leksykalnych są to np. +rzeczownik $(+\mathrm{N})$, +czasownik $(+\mathrm{V})$, itd. Do kategorii funkcjonalnych należą m.in. cechy odpowiedzialne za fleksję ( \pm Infl), czas gramatyczny 
$( \pm T)$, zgodę ( $( \pm$ Agr), itd. W języku angielskim występują także m.in. kategorie modalności (realizowana przez czasowniki modalne), aspektu (odzwierciedlona morfologicznie w końcówkach imiesłowów), środka czynności (widoczna np. w użyciu partykuł ograniczających up lub down), itd.

W przeciwieństwie do wcześniejszych modeli gramatyki generatywnej, w Programie Minimalistycznym cechy formalne nie są nadawane w trakcie derywacji, ale już przed, w trakcie procesu Numeracji, czyli pierwszego etapu tworzenia konstrukcji składniowych (Chomsky 1995a, 1998). Cechy formalne mogą być postrzegane jako 'katalizatory' procesów składniowych ${ }^{17}$, a głównym celem derywacji jest ich eliminacja, jako że nie podlegają one interpretacji na odpowiednich poziomach (Formie Fonologicznej i Formie Logicznej).

Jednym z głównych założeń metodologicznych gramatyki generatywnej zawsze było ograniczanie do niezbędnego minimum aparatu teoretycznego. $\mathrm{Z}$ drugiej zaś strony wprowadzenie nowego elementu do teorii niejednokrotnie powodowało jego nadużywanie w celu wyjaśniania nowych problemów i opisywania różnych konstrukcji gramatycznych. Tak stało się z transformacjami w teorii standardowej i z abstrakcyjnymi predykatami w semantyce generatywnej. By zapobiec nieograniczonemu 'pączkowaniu' kategorii funkcjonalnych, H. Thráinsson (1996) wprowadził na grunt gramatyki generatywnej brzytwę Ockhama, w postaci tak zwanej 'zasady prawdziwego minimalizmu' (Real Minimalist Principle), która głosi, że należy postulować istnienie tylko tych kategorii funkcjonalnych, które są realizowane (na poziomie morfo-składni). Również w myśl sformułowanej przez D. Boucharda (1995) 'zasady pełnej interpretacji' (Principle of Full Interpretation), każdemu (morfo-)składniowemu elementowi zdania musi odpowiadać element w reprezentacji semantycznej, a każdy element reprezentacji semantycznej musi być identyfikowany przez jakiś element (morfo-)składniowy. Interpretacji semantycznej (w nieformalnym rozumieniu tego terminu) należy dokonać na gruncie określonego typu semantyki.

\section{Kontrowersje}

Od samych swych początków gramatyka generatywna w ujęciu Chomsky’ego była poddawana krytyce, zarówno ze strony językoznawców podzie-

17 Jest to sformułowanie Jacka Witkosia. 
lających formalne zainteresowania strukturą języka, jak i językoznawców bardziej zainteresowanych funkcją języka, semantyką, pragmatyką, aktami mowy, dyskursem czy socjolingwistyką.

Kwestią budzącą znaczne kontrowersje, od momentu powstania gramatyki generatywnej, jest miejsce semantyki w generatywnym opisie języka ${ }^{18}$. Podejście do problemów znaczenia jest, obok koncepcji modularności języka, jednym $\mathrm{z}$ elementów silnie odróżniających generatywizm od językoznawstwa kognitywnego (w wersji zarówno Langackera, jak i Lakoffa czy Talmy'ego). W swoich najwcześniejszych pracach Chomsky podkreślał, że teoria lingwistyczna składa się z dwóch podstawowych części: składni oraz semantyki (np. Chomsky [1955]: 57), później jednak wykluczył semantykę (referencyjną) z pola widzenia teorii lingwistycznej. W nowszych pracach twierdzi wręcz, że na język naturalny składa się jedynie składnia i pragmatyka ('it is possible that natural language has only syntax and pragmatics', Chomsky 1995b: 26, 2000: 132). Natomiast w obrębie szeroko pojętego językoznawstwa generatywnego spory dotyczyły zwłaszcza zastosowania transformacji, istnienia kategorii pustych, a także modularności i relacji pomiędzy komponentem składniowym a semantycznym. Wieloletnie kontrowersje i spory doprowadziły z jednej strony do daleko idących zmian w modelu Chomsky'ego, a z drugiej do powstania licznych 'konkurencyjnych' podejść i teorii ${ }^{19}$. Pojawiły się również istotne metodologiczne zastrzeżenia związane z samym rozwojem teorii generatywnej, a w ostatnich latach zwłaszcza z przejściem od teorii rządu i wiązania do minimalizmu.

We wstępie do tomu swoich wczesnych artykułów poświęconych minimalizmowi (The Minimalist Program, 1995), Chomsky zauważa, że obszar badawczy gramatyki generatywnej ulega szybkim przemianom ze względu na wpływ nowych danych empirycznych oraz zagadnień teoretycznych, dodając, że „to, co dzisiaj wygląda na uzasadnione rozwiązania, może przybrać zupełnie inną formę jutro" (Chomsky 1995a: 10). Nie wszyscy jednak podzielają opinię Chomsky’ego, że zmiana paradygmatu jest rzeczywiście uzasadniona nowymi faktami empirycznymi.

18 Zob. opracowanie J. D. Fodor (1980) poświęcone roli semantyki we wcześniejszych modelach gramatyki generatywnej oraz Willim (2010) na temat ewolucji poglądów na semantykę w podejściu generatywnym.

19 Znakomitym opracowaniem tzw. wojen językoznawczych jest praca Harrisa (1995), zob. także historiograficzne opracowania Newmeyera $(1983,1986)$. 
W najnowszej literaturze polskiej gruntowną krytykę generatywizmu przeprowadził, na gruncie ogólnej metodologii nauk, Paweł Więckowski (2008). Więckowski krytycznie analizuje m.in. empiryczną przydatność testów składniowych, arbitralność proponowanych struktur składniowych, status pustych kategorii, a także typy praw i sposób ich uzasadniania. Po dokładnej analizie metodologicznej struktury kolejnych teorii generatywnych (od teorii standardowej po teorię rządu i wiązania) stara się on wykazać ich jedynie powierzchowne podobieństwo do prawdziwych teorii naukowych, jak zauważa, teoria generatywna „ma dostarczać wiedzy o rzeczywistości obserwowalnej, a jednak jest niewrażliwa na fakty, gdyż każdy fakt potrafi zinterpretować i pogodzić z założeniami, na których jest oparta" (Więckowski 2008: 102).

Kontrowersja związana z postrzeganiem minimalizmu jako zmiany paradygmatu była przedmiotem szeregu artykułów sprowokowanych wystąpieniem Lappina, Levina i Johnsona (2000). W krótkim komentarzu zamieszczonym w piśmie Natural Language and Linguistic Theory podważyli oni metodologiczną zasadność, na gruncie sposobu budowania teorii, przejścia od teorii rządu i wiązania do programu minimalistycznego, zwrócili też uwagę na brak wystarczającej empirycznej podbudowy programu minimalistycznego oraz na chybione porównanie językoznawstwa generatywnego (w wersji Chomsky’ego i jego szkoły) do nauk przyrodniczych i ścisłych. Ten komentarz zaowocował długą wymianą na łamach $N L L T$, ale nie doprowadził do żadnych konstruktywnych ustaleń, zob. podsumowanie w Freidin i Vergnaud (2001). Ta kontrowersja z pewnością zasługuje na odrębne omówienie. Do innych bardzo krytycznych opracowań programu minimalistycznego, również o charakterze metodologicznym, należy też książka Pietera Seurena (2004). Seuren w kolejnych rozdziałach omawia poszczególne elementy programu minimalistycznego, podważa jego spójność, krytykuje zasadność przyjmowania kolejnych wersji gramatyki generatywnej, podkreśla liczne niekonsekwencje $\mathrm{w}$ postulowanym modelu, a także brak odpowiednich danych empirycznych. Książka Seurena w zamierzeniu autora miała sprowokować szeroką dyskusję na temat metodologicznych założeń współczesnej gramatyki generatywnej Chomsky’ego, tymczasem spotkała się z bardzo ograniczoną reakcją, natomiast dość charakterystyczna była wysoce krytyczna recenzja Roberta Fiengo (2006). Warto przytoczyć jeden fragment, który doskonale ilustruje 'ideologiczny' (czy może nawet 'dogmatyczny’) wymiar kontrowersji. Fiengo, podkreślając odkrywczość myśli 
Chomsky' ego, zauważa, że mamy do czynienia z kimś, kto ilekroć siada do pracy, to stara się na nowo odkryć swoje pole badawcze i dlatego nie należy od niego oczekiwać posługiwania się powszechnie przyjętymi metodami naukowymi (czymkolwiek te miałyby się okazać) ${ }^{20}$. Apologetyczny (i dogmatyczny) charakter tego typu uwag całkowicie uniemożliwia dyskusje na temat metodologicznych założeń minimalizmu i pokazuje, niejako na przekór cytowanym powyżej słowom Alfreda Ayera, że postęp (w językoznawstwie i filozofii języka), choć uwzględnia stawianie nowych pytań i śmiałych hipotez, to nie eliminuje, niestety, sporów o charakterze sekciarskim.

\section{Bibliografia}

Abraham W., Epstein S. D., Thráinsson H., Zwart J.-W. (red.), 1996, Minimal Ideas. Syntactic Studies in the Minimalist Framework, Amsterdam \& Philadelphia: John Benjamins Publishing Company.

Ayer A. J., [1982] 2000, Filozofia w XX wieku (tłum. T. BASZnIAK), Warszawa: Wydawnictwo Naukowe PWN.

Barsky R. F., 1998, Noam Chomsky: A Life of Dissent, Cambridge, MA: The MIT Press.

Bloomfield L., 1926, A Set of Postulates for the Science of Language, Language 2(3), s. $153-164$.

Bobrowski I., 1998, Zaproszenie do językoznawstwa, Kraków: Instytut Języka Polskiego PAN.

Bobrowski I., 2009, O dwóch kognitywizmach, Biuletyn Polskiego Towarzystwa Językoznawczego LXV, s. 57-65.

Bouchard D., 1995, The Semantics of Syntax, Chicago \& London: The University of Chicago Press.

Сномsкy N., [1955] 1975, The Logical Structure of Linguistic Theory, Chicago: Chicago University Press.

Chomsky N., 1957, Syntactic Structures, The Hague: Mouton.

Сномsкy N., 1965, Aspects of the Theory of Syntax, Cambridge, Mass.: MIT Press (Zagadnienia teorii sktadni, 1982, tłum. I. Jakubczak, Wrocław: Ossolineum).

Сномsкy N. [1966] 2009, Cartesian Linguistics. A Chapter in the History of Rationalist Thought, New York: Harper \& Row (trzecie wydanie: Cambridge: Cambridge University Press).

20 „Let us remember that we are talking about someone who tries to reinvent the field every time he sits down to write. Why should we expect Chomsky to follow normal scientific practice, whatever that might be?" (Fiengo 2006: 47). 
Сномsку N., 1980, On Binding, Linguistic Inquiry 11, s. 1-46.

Сномкку N., 1981, Lectures on Government and Binding, Dordrecht: Foris.

Сномsкy N., 1982, Some Concepts and Consequences of the Theory of Government and Binding, Cambridge, Mass.: MIT Press.

Сномsкy N., 1986, Knowledge of Language: Its Nature, Origin and Use, New York: Praeger.

Chomsky N., 1995a, The Minimalist Program, Cambridge, Mass.: MIT Press.

Сномsку N., 1995b, Language and nature, Mind 104, s. 1-61.

Сномкку N., 1998, Minimalist Inquiries: the Framework, MIT Occasional Papers in Linguistics 15, MITWPL, Department of Linguistics and Philosophy, MIT, Cambridge, MA.

Сномsкy N., 2000, New Horizons in the Study of Language and Mind, Cambridge: Cambridge University Press.

Сномsкy N., 2002, On Nature and Language, Cambridge: Cambridge University Press.

Chомsкy N., 2005, Three Factors in Language Design, Linguistic Inquiry 36, s. 1-22.

Сномкку N., 2007, Biolinguistic Explorations: Design, Development, Evolution, International Journal of Philosophical Studies 15(1), s. 1-21.

Evans-Pritchard E. E., 1951, Social Anthropology, London: Cohen \& West Ltd.

FIENGo R., 2006, Review of Chomsky's Minimalism, Mind 115, s. 469-472.

Fodor J. D., 1980, Semantics. Theories of Meaning in Generative Grammar, Cambridge, Mass.: Harvard University Press.

Frege G., [1891] 1977, Funkcja i pojęcie, w: tenże, Pisma semantyczne, tłum. B. Wolniewicz, Warszawa: PWN, s. 18-44.

FREGE G., [1879] 1997a, Ideografia. Język formalny czystego myślenia wzorowany na języku arytmetyki, w: F. Brentano, G. Frege, Ch. Thiel, Próby gramatyki filozoficznej. Antologia (tłum. K. Rotter), Wrocław: Wydawnictwo Uniwersytetu Wrocławskiego, s. 45-85.

FreGE G., [1906] 1997b, Letters to Husserl, 1906 (translated by H. Kaal), w: M. Beaney (red.), The Frege Reader, Oxford: Blackwell Publishers, s. 301-307.

Freidin R., Vergnaud J.-R., 2001, Exquisite connections: some remarks on the evolution of linguistic theory, Lingua 111, s. 639-666.

Goodman N., [1978] 1997, Jak tworzymy świat (tłum. M. Szczubiałka), Warszawa: Fundacja Aletheia.

Harris R. A., 1995, The Linguistics Wars, Oxford: Oxford University Press.

JACKendoff R., 2002, Foundations of Language. Brain, Meaning, Grammar, Evolution, Oxford: Oxford University Press. 
Jackendoff R., 2007, Language, Consciousness, Culture. Essays on Mental Structure, Cambridge, Mass.: MIT Press.

Kunn T., [1962] 2001, Struktura rewolucji naukowych (tłum. H. Ostromęcka), Warszawa: Fundacja Aletheia.

Kurcz I., 2011, Charakterystyka kompetencji językowej - reprezentacje umysłowe, w: I. Kurcz i H. Okuniewska (red.), s. 80-124.

Kurcz I., OKuniewska H. (red.), 2011, Język jako przedmiot badań psychologicznych, Warszawa: Wydawnictwo „Academica”.

Lappin S., Levine R., Johnson D., 2000, The Structure of Unscientific Revolutions, Natural Language and Linguistic Theory 18, s. 665-671.

Lasnik H., 2000, Syntactic Structures Revisited, Cambridge, Mass.: MIT Press.

LeEs R., 1957, Review of Syntactic Structures by Noam Chomsky, Language 33, s. $375-408$.

Ludlow P., 2011, The Philosophy of Generative Linguistics, Oxford: Oxford University Press.

McGilvray J., 2009, Introduction to the third edition, w: N. Chomsky [2009], s. 1-52.

MeCner P., 2005, Elementy gramatyki umystu, Kraków: Universitas.

Newmeyer F. J., 1983, Grammatical Theory. Its Limits and Its Possibilities, Chicago: The University of Chicago Press.

Newmeyer F. J., 1986, The Politics of Linguistics, Chicago: The University of Chicago Press.

Pawelec A., 2008, Mentalizm w badaniach nad językiem, w: P. Stalmaszczyk (red.), Metodologie językoznawstwa. Współczesne tendencje i kontrowersje, Kraków: Lexis, s. 105-119.

Rizzi L., 2004, On the study of the language faculty: Results, developments, and perspectives, The Linguistic Review 21, s. 323-344.

Rotter K., 1997, Próba gramatyki filozoficznej. Antologia, Wrocław: Wydawnictwo Uniwersytetu Wrocławskiego.

SAussure de F., [1915] 1991, Kurs językoznawstwa ogólnego (tłum. K. Kasprzyk), Warszawa: PWN.

Searle J., [2004] 2010, Umyst. Krótkie wprowadzenie (tłum. J. Karłowski), Poznań: Rebis.

Seuren P., 2004, Chomsky's Minimalism, Oxford: Oxford University Press.

Stalmaszczyk P., 1995, Gramatyka generatywna Noama Chomsky'ego a lingwistyka stosowana, Folia Linguistica 33, s. 119-136.

Stalmaszczyk P., 2006, Gramatyka generatywna w poszukiwaniu istoty języka, Kwartalnik Pedagogiczny 4 (202), s. 113-131.

Stalmaszczyk P., 2011, Problemy metodologiczne współczesnego generatywizmu, czyli składnia generatywna uzupełniona o semantykę pojęciową [w druku]. 
Stalmaszczyk P. (red.), 2006, Metodologie językoznawstwa. Podstawy teoretyczne, Łódź: Wydawnictwo Uniwersytetu Łódzkiego.

Stalmaszczyk P. (red.), 2008, Metodologie językoznawstwa. Współczesne tendencje i kontrowersje, Kraków: Lexis.

TAJSner P., 2006, Minimalizm. Przełom i kontynuacja, w: P. Stalmaszczyk (red.), s. 91-107.

THRÁINSSON H., 1996, On the (non-)universality of functional categories, w: W. Abraham et al. (red.), s. 253-281.

Tomalin M., 2006, Linguistics and the Formal Sciences. The Origins of Generative Grammar, Cambridge: Cambridge University Press.

WięcKowski P., 2008, Młot na językoznawców, czyli o metodologii generatywizmu Chomsky'ego, w: P. Stalmaszczyk (red.), s. 43-104.

WiLlim E., 2010, O sporach wokół formy i funkcji we współczesnym językoznawstwie. Formalizm kontra funkcjonalizm?, Linguistica Copernicana 3, s. 81-127.

Witkoś J., 2000, Program minimalistyczny: podstawowe założenia i przykłady derywacji zdań w języku polskim, Polonica 20, s. 5-22.

Wiткоś J., 2008, Program minimalistyczny a językoznawstwo porównawcze, w: P. Stalmaszczyk (red.), s. 206-224.

Wittgenstein L., [1922] 1997, Tractatus Logico-Philosophicus (tłum. B. Wolniewicz), Warszawa: Wydawnictwo Naukowe PWN.

Wolniewicz B., 1977, Semantyka Fregego, w: G. Frege, Pisma semantyczne, Warszawa: PWN, s. vii-xxxii.

WRóBel S., 2010, Umyst, gramatyka, ewolucja, Warszawa: Wydawnictwo Naukowe PWN.

\section{Historical and methodological background of contemporary generative grammar}

\section{( su m mary)}

The paper discusses the historical and methodological background of Chomsky's generative enterprise. It briefly characterizes the context in which generative grammar developed, concentrating on Frege's logic and linguistic structuralism (Saussure's and Bloomfield's), and points to the differences in these approaches. The main part of the paper discusses the notion of language as defined by Chomsky, from his earlier writings (such as Syntactic Structures, 1957), through Government and Binding theory, to the more recent Minimalist Program, and studies concerned with biolinguistcs. The major claim of the paper is that the early model of generative grammar, especially its formalism and description of generative mechanisms (phrase structure rules, transformations, account of natural language recursion) has survived the test of time. Whether this will be the case with the biolinguistic claims of the more recent developments within generative grammar remains to be seen. 